Jurnal Syntax Imperatif: Jurnal Ilmu Sosial dan

Pendidikan

p-ISSN: 2721-2491 p-ISSN: 2721-2246

Vol. 2, No. 1, Maret 2021

\title{
The Ability of The Second Years Students of SMAN 2 Sungai Penuh in Using Question Tags
}

\section{Yelnim, Sukarta Kartawijaya, Intan Sherlin}

Sekolah Tinggi Ilmu Ekonomi (STIE) Sakti Alam Kerinci, Indonesia

animstiesak@gmail.com, arumisyakira@gmail.com, intansvsi@gmail.com

\begin{abstract}
This reseach is aimed at analyzing the ability of the scond years student's of SMAN 2 Sungai Penuh in using qestion tag. This research was done at SMAN 2 Sungai Penuh. The prposes of the reseach are (1) To know the student's ability ini using tag in English sentences. (2) To Know, what the student's weakness using question tag in English sentences.(3)To now, wha the efort taken by teacher to improve student's ability using question tag in English Sentences. The analysis focuses on learning about question tag. The data are collected by using obsevational method in collecting data, gives test some student's with 20 item test. The informan of the reseacrh is 10 student's each of class as sample. The analysis is coducted by using descripive quantiative method which is meant to envelope fact, situation, variable and phenomenon that happen a te time when the reseach takes places and present in with reality. The result shows that the student wakness in using question tag in english sentences. (1) the ability of student in using question tag in sentences low category with score $57 \%$ (2) the stdents did not know concept in each of sentences. (3) the student could not difference word that added $s$ or es.
\end{abstract}

Keywords: Ability; Question Tag; Students;

\section{Introduction}

Learning language is learning for communication, spoken or written. There are many languages in the world one of them is English language. English consisting of four skills; speaking, reading, writing, and listening. All of the skill needs understanding or improving using grammar to be true sentences. So,that. The students' must study about grammar. In learning grammar the students' learn about quesion tag. A question tag or tag question is grammatical structure $n$ which a declarative statement or an imperative is turned into aquestion by adding an interrogative fragment ("the tag"). For example, in the sentences "You're John, aren't you?", yhe statement "You're John" is turned intoa question by the tag "aren't you". Question tag are the short question adding after positive negative sentences, that we put on the end of sentences - perticularly in spoken English. There are lots of different question tag but he rules are not dfficult to learn. We use tag in spoken English but not in formal written English.

They are not really questions but are a way of asking the other person to make a comment and so keep the conversation open. Making a tag is very mechanical. To make a tag, use the first auxiliary. If there is no auxiliary, use do, does or did. With a positive sentence, make a negative tag ad with a negaive sentence, make a positive tag. English is very important to prepare the learners of English as a foreign languange can be competitiveas the human resource in their life. There are infinite procedures teachers 
use to achieve desired effects from their students, but there are general patterns these motivational tools follow.

Then to improve our skill in English the students have study about gramar, in English grammar we are study about qustion tag. The gramar importance to know, it is useful to get mean of sentences. Senior high school (SMAN 2) Sungai Penuhis one school in Sungai Penuh city, ditrict of Kerinci, and they have learning about question tagbut based on the researcher's observation and test some students still make mistakes in using question tag in English sentences. When the reseacher interviewed the English teacher in SMAN 2 Sungai Penuh, the teacher gives information "I have tense them about question tag for three meetings but they still make mistake when I give the test".

This resacrh was done at SMAN 2 Sungai Penuh. The purpose of the reeachwas known the ability of the students $i$ using question tag. SMAN 2 Sungai Penuh is one of senior high school in Sunga Penuh Town. Beside on researcher observation in the school and interview some students', they have been learning about question tag for the meetings. So, the researcher is interested to research about the students' ability and their weaknesses in using question tag.

\section{Definition}

Question tag is a question aded to a declarative sentence, usually at the end, to engage the listener,verify hat something has been understod, or confirm that an action has occured. Also known as a question tag. Common tags include won't you? Wasn't you? Wasn't it? Don't you? Haven't you? Okey? And right. A question tag or tag question is a grammatical structure in which a declarative statement or an imperative is turned into a question by adding an interrogative fragment (the tag). For example, in the sentence "You're John, aren't you?", the statement "You're John" is turned into a question by the tag"'are't you". The term "question tag" is generally is preferred bu British grammarians, while their American counterparts prefer "tag question".

A tag question is a special construction in English. It is a statement followed by a mini-question. The whole sentence is a tag question, and the mini-question at the end is called a "question tag". A tag is something small that we add to something larger. For example, , the little piece of cloth added to a shirt showing size or washing instructions is a tag. We use tag questions at the end of statements to ask for confirmation. They mean something like: Am I right? or Do you agree? They are very common in English.

\section{Method}

These research is descriptive quantitative in nature. Descriptive quantitative research is meant to envelope fact, situation, variable and phenomenon that happens at the time when the research takes place and present is with reality". This research was conducted at second class SMA Negeri 2 Sungai Penuh. 


\section{Population}

"Population is the group of interest to research. So, in this research the populations are all of second year students of SMA Negeri 2 Sungai Penuh and the English teacher.The number of population is 124 students consisting of IIA, 11B, and IIC. The reason for choosing students second year studens as population of this research because thisclass had studied about question tags. Based on the researched s interview with the English teacher where he tense explanation.

\section{Sample}

"Sample is part of respondent or representative of population that will investigate The other definition, Sampling is processof selecting in the number of individual for study in such a way that they represent the large group which was the researcher selected and there are two kind of procedure collecting sample: I. Take sample by random sampling, 2. Take sample by cluster sampling one-stage cluster sample occurs when the researcher includes all the high school students from all the randomly selected Clusters as sample.ln an Oxford dictionary, "Sample is one of a number of people or things or part of a whole, used for showing what the rest in the like. Test a small amount of something to see what it is like".ln this thesis the researcher used spelling sampling, where all of students' name writes in small paper and then put in empty box, then try to put out one by one of the names to be sample. Total sample are 30 students. From the table above each of class got ten students.

\section{Data Collection}

Observation is a method in collecting data in this research to get information about someone activities Observation method is the method firstly researcher does in this thesis, before give a test the researcher will observation when English teacher give material to the students and observation what media the teacher use in improving English students ability, and then observation students' ability and motivation in company learning process. In this thesis the researcher give test items to the students as sample and students answer according statements given in the items test.Kind of this test is multiple-choice test and the numbers of items are 20 items. Each of items contains four alternative answer (A, B, C, D. and one of them is correct answer. The respondents can chose the correct answer based on alternative given. If the students answer one correctly score is 5 and if all the students answers are true, the total score is 100 .

\section{Documentation}

Documentation method is part of important method to collect the data in this research. Documentation method looked for the data about problem or variable like notes, transcription, books and newspaper. In this research the researcher use documentation method by taking the important document in SMA Negeri 2 Sungai 
Penuh like: History, Geography, teacher condition, students condition, structure organization, and other important documents in SMA Negeri 2 Sungai Penuh.

\section{Procedure of the Research}

1. Choosing sample by clustering sampling, chose 10 students each of class. ( see appendix 11 )

2. Giving test. The test giving to the sample the test the test consist of 20 items test the type is multiplechoice test. where students can answer between A, $\mathrm{B}, \mathrm{C}$, or D alternatives.

\section{Data Analysis}

A data analysis is a comprehensive summary of the results of your research and lists the main conclusions drawn from tests and experiments. The analysis typically summarizes two main parts of a research document: data preparation and descriptive statistics (experimental studies) and inferential statistics (quantitative studies). The final section is the qualitative analysis that explains why some types of results are relevant. In this thesis the researcher analysis students test.

\section{Result and Discussion}

Analysis Students' Test

To know the students ability using question tag in English sentences, the researcher will give 20 items test and score for each items is 5 all of score are 100 then researcher using scale AnasSudijono there five point scale, they are excellent, good, enough, poor, very poor. In analyzing test score for students the researcher using percentage formula, like follow:

$$
P=\frac{F}{N} x 100 \%
$$

Which in: Percentage of the category. F:Number of sample in thecategory. N :Total number of sample

Validity is the most important consideration in test evaluation. The concept refers to the appropriateness, meaningfulness, and usefulness of the specific inferences made from test scores. Test validation is the process of accumulating evidence to support such inferences. A variety of inferences may be made from scores produced by a given test, and there are many ways of accumulating evidence to support any particular inference. Validity, however, is a unitary concept. Although evidence may be accumulated in many ways, validity always refers to the degree to which that evidence supports the inferences that are made from the scores. It is the inferences regarding specific uses of a test that are validated, not the test itself.

The determine index difficulty of the items in tryout score, the researcher use formula: 


$$
P=\frac{B}{J S}
$$

To give interpretation on numeral of difficulty items, the researcheranalysis was based on the formula.

Item discrimination of the test is a test power that can differentiate students who have high capability and low capability. To find out item discrimanition, the researcher used the formula suggested by arikunto, as follow:

$$
P=\frac{B A}{J A}-\frac{B B}{J B}
$$

Where:

$\mathrm{P}=$ items discrimination

BA = proportion of the high group who anwers correctly

$\mathrm{BB}=$ proportion of the low group who anwers correctly

$\mathrm{JA} / \mathrm{JB}=$ sum of the student who follow the test

The result of item discrimination is classified into the following:

$\mathrm{D} \quad=0,00-0,20$ : poor

$\mathrm{D} \quad=0,20-0,40 \quad$ : average

$\mathrm{D} \quad=0,40-0,70 \quad: \operatorname{good}$

$\mathrm{D} \quad=0,70-1,00$ : very good

Each of items test is reliable if the test can give result of which is relative remain to conducted by recurring at is same individual group. To get reliable of the items test the researcher using the following formula:

$$
R I I=\left(\frac{n}{n-1}\right)\left(\frac{S^{2}-\sum P q}{s^{2}}\right)
$$

In which :

RII $=$ The Reliability of test

$\mathrm{N} \quad=$ The number of items

$\mathrm{p} \quad=$ The num ber of students

$\mathrm{q}=$ The num ber of student answer wrong.

\section{Conclusions}

The ability of students in using question tag in the sentences was low category with score $57 \%$ (low ability). Students' did know concept in each of sentences (if positive sentence question tag negative and if negative sentence question tag positive) Until many students done wrong in positive sentence and question tags negative at using do or does. Students can't difference words that add s or es. Many students according that it is noun who add s or es. In increasing students creativity in learning English not only participation and method from teachers but need participation from students selves. 
Yelnim, Sukarta Kartawijaya, Intan Sherlin

Students have to grow big spirit make English very importance for them, and know English is international language all of country use English in communicate between country. Beside that English is National curriculum all students must success in last test if the students would like to continue their study. So, all students mush know learning English the same by learning Indonesia. 


\section{BIBLIOGRAPHY}

Arikunto, Dasar-Dasar Evaluasi Pendidikan Edisi Refisi. (Jakarta: PT. BumiAksara, 2005), p.150

Betty SchrampferAzar, Fundamental of English Grammar, (Printed in The United States: American, 2003), 152

Depertemen Agama RI, Al-Quean Al-Karim, (Jakarta, Yayasan Penyelengara Penterjemah / Penapsir Al-quran,1993). 281

Masri Singarabu, dkk, Metode Penelitian Survei, (Jakarta: LP3ES, 1989), p. 155

M.Subana and Sudrajad, Pengantar Evaluasi Pendidikan, (Jakarta: PT. Persada, 2006), p. 133.

M. Sudrajat, Dasar-Dasar Penelitian Ilmiah, (Bandung: CV. PustakaSetia, 2005), p. 26

S. Nasution, Metode Research, (Jakarta: BumiAksara, 2008), p.106

University express, Oxford Dictionary, (New York: Oxford University Press), p. 379. 